ACTA AGROBOTANICA

Vol. 54, z. 2 - 2001

s. $19-25$

\title{
Flavonoids in white and yellow perianths and yellow anthers of tulips (Tulipa gesneriana L.)
}

\section{MARCIN HORBOWICZ ${ }^{1}$, MARIAN SANIEWSKI ${ }^{2}$}

\author{
'Research Institute of Vegetable Crops, Konstytucji 3 Maja 1/3, \\ 96-100 Skierniewice, Poland, \\ ${ }^{2}$ Research Institute of Pomology and Floriculture, Pomologiczna 18, \\ 96-100 Skierniewice, Poland
}

(Received: 14.05.2001)

\section{Sum mary}

The content of flavonoids in white and yellow perianths and yellow anthers of a few tulip cultivars were determined at the stage of full flowering. To analyses of flavonols a HPLC method was used. In anthers (yellow) of all analyzed cultivars (Oscar, Pax, Profesor Wóycicki, Biała Dama, White Virgin, Calypso, Diana) high content of quercetin (2.35 - $6.01 \mathrm{mg} \cdot \mathrm{g}^{-1}$ F.W.), kaempferol (1.09 - $9.47 \mathrm{mg} \cdot \mathrm{g}^{-1}$ F.W.) and apige$\operatorname{nin}\left(1.34-8.24 \mathrm{mg} \cdot \mathrm{g}^{-1} \mathrm{~F} . \mathrm{W}\right.$.) was found. In analyzed white perianth of cvs. Oscar and White Virgin also high content of quercetin (1.3 - $1.80 \mathrm{mg} \cdot \mathrm{g}^{-1}$ F.W.) and kaempferol $\left(1.90 \mathrm{mg} \cdot \mathrm{g}^{-1}\right.$ F.W.) was documented and only traces of apigenin was found. In the yellow perianth of cv. Profesor Wóycicki the level of quercetin and kaempferol was much lower than in perianth of cvs. Oscar and White Virgin, and apigenin was absent. Thus, yellow anthers and white and yellow perianth of tulip cultivars are a rich source of flavonols.

Key words: tulip, Tulipa gesneriana, flavonoids, perianth, anthers, quercetin, kaempferol, apigenin 


\section{INTRODUCTION}

Flavonoids are a large group (more than 4000 of flavonoids have been reported) of naturally occurring compounds (I w a s h in a, 2000). Flavonols are flavonoids of particular importance as they are have been found to posses antioxidant and free radical scavenging activity ( $\mathrm{P}$ i e t $\mathrm{t}$ a, 2000). Among them flavonols (flavan-3,4diols) - quercetin, kaempferol and myricetin are widely distributed within the plant kingdom (H a r b o r n e, 1994; F o r m i c a and R e g e l s o n, 1995).

Flavonoids take part in defense system against attack of pathogens, insects and stress conditions during plant growth and development ( $\mathrm{H}$ a r b o r n e, 1994; T o m a s - B a r b e r a n et al., 1988). They play important role in auxin biosynthesis and are responsible for colour and taste of plant tissues as well (M o o r e, 1989). Therefore composition and concentration of flavonoids can attracts or repels the insects as a flower pollinators ( $\mathrm{H} \mathrm{e} \mathrm{d} \mathrm{i} \mathrm{n} \mathrm{and} \mathrm{W}$ a n g e a, 1986). It was found too that flavonoids protect plants against free radicals and oxidative damages caused by UV radiation present in sunlight ( $\mathrm{L}$ a r s o n, 1988).

Vegetables, fruits and beverages are the main dietary sources of flavonols, primarily as quercetin and kaempferol ( $\mathrm{H}$ e $\mathrm{r} \mathrm{r} \mathrm{m}$ a $\mathrm{n} \mathrm{n}, 1988$; $\mathrm{T}$ o y o d a et al., 1997; $\mathrm{M} \mathrm{arke} \mathrm{n}$ and B e e c h e r, 2000). One of the major sources of flavonols in the European diet is the onion and some other Allium crops (H e r t o g et al., 1992; $\mathrm{H}$ o r b o w i c z, 2000). Among onion cultivars high level of quercetin glycosides were found in brown-skinned and red-skinned cultivars. In fleshy scales of brownskinned onions cultivated in Poland, the concentration of quercetin ranged from 0.298 to $0.828 \mathrm{mg} \cdot \mathrm{g}^{-1}$ of fresh weight ( $\mathrm{H} \mathrm{o} \mathrm{r} \mathrm{b} \mathrm{o} \mathrm{w} \mathrm{i} \mathrm{c} \mathrm{z} \mathrm{and} \mathrm{K}$ o t l i ń s k a, 1998). Exceptionally rich in quercetin (mainly in free form) are dry brown and red outer scales of onion (10 - 30 mg $\cdot \mathrm{g}^{-1}$ dry weight). White cultivars of onion (dry outer scales as well as fleshy scales) contain only traces of quercetin (H o r b o w i c z, 2000).

Colours of onion dry scales (deep yellow or light brown) and inner fleshy scales (light yellow) is caused by quercetin in free form, and glycosides of quercetin, respectively. Pure aglycones and glycosides of quercetin, kaempferol and apigenin have yellow colour or light brown.

Colour of plant tissues is a composition of three main classes of natural pigments: carotenoids, chlorophylls and flavonoids. In blooming flowers occur carotenoids, anthocyanins and flavonols glycosides.

Different flavonols were identified in tulip (Tulipa gesneriana L.) organs, leaves, perianth and pollen (S t r a c k et al., 1981; B u d z i a n o w s k i, 1991). However, most literature concerns identification and measurements of anthocyanidins in tulip perianths, anthers and pollens ( $\mathrm{N}$ a $\mathrm{k}$ a y a m a et al., 1999; $\mathrm{N} \mathrm{i} \mathrm{e} \mathrm{u} \mathrm{w} \mathrm{h} \mathrm{of} \mathrm{et}$ al., 1990; V a n R a am s d on k, 1993; H a l ev y and A se n, 1959; S h i b a t a and I s hikura, 1959; S h ib a t a and Y os hit a ma, 1968; S hib a t a and S a k a i, 1961; Torsk ang erpoll et al., 1999).

The aim of this work was to determine the content of some flavonoids in perianths and anthers of a few white and yellow tulip cultivars. 


\section{MATERIAL AND METHODS}

\section{Plant material}

The perianths (white and yellow) and anthers (yellow) from a few cultivars of tulip (Tulipa gesneriana L.) (Tab. 1) were collected separately at full flowering from the garden of the Research Institute of Pomology and Floriculture at Skierniewice, Poland.

\section{Description of chemical analyses}

The flavonols content was determined according to method based on $\mathrm{P}$ a t i l et al. (1995) procedure with many own modifications (H o r b o w i c z, 1999). Twenty plants were taken to analyses. After knife cutting a $20 \mathrm{~g}$ samples of perianths tissue were blended with 10 -fold $(\mathrm{v} / \mathrm{w})$ portion of $60 \%$ ethanol-water solution (in case of anthers $0.5 \mathrm{~g}$ samples were homogenized with 20 -fold volume of $60 \%$ ethanol-water). Followed the samples were kept overnight at ambient temperature, and then filtered over medium speed filter paper. To $1.5 \mathrm{ml}$ aliquots placed in screw-capped vials $0.5 \mathrm{ml}$ $6 \mathrm{~N} \mathrm{HCl}$ was added, and flavonoid glycosides were hydrolysed at $100^{\circ} \mathrm{C}$ during 30 $\mathrm{min}$. Then one $\mathrm{ml}$ of water was added to hydrolysate and obtained aglycones were extracted by three times vigorous shaking with $1 \mathrm{ml}$ of ethyl acetate. Separated upper layer was withdrawn using Pasteur pipette. Pooled acetate layers were diluted with methanol : water solution $(1: 1, \mathrm{v} / \mathrm{v})$.

\section{HPLC conditions}

To analyses of flavonols a LKB (Sweden) HPLC apparatus equipped with Rheodyne 7125 injection system ( $20 \mu \mathrm{l}$ loop), UV detector (2151 Variable Wavelength Monitor) set at $370 \mathrm{~nm}$, and Shimadzu C-R6A Chromatopac integrator was used. The flavonols were isocratically separated on Lichrosorb RP18 (4 x $250 \mathrm{~mm}, 10 \mu \mathrm{m})$ column, and a mobile phase was methanol: water mixture $(55: 45, \mathrm{v} / \mathrm{v})$ contained $0.2 \%$ ortho-phosphoric acid. The flow rate was $0.8 \mathrm{ml} / \mathrm{min}$.

Standards of flavonoid aglycons for analysis were purchased from Sigma (quercetin) and Fluka (kaempferol and apigenin). The standard curves was prepared for concentration range 0.2 to $10.0 \mu \mathrm{g} / \mathrm{ml}$.

Analyses were done in three replicates, and results were statistically calculated by use t-Student (standard deviation). 


\section{RESULTS AND DISCUSSION}

White and yellow perianths of investigated tulip cultivars contained a relatively high level of quercetin and kaempferol glycosides, and traces of apigenin only (Fig. 1).

Table 1. Contents of flavonoids in yellow anthers of several tulip cultivars.

\begin{tabular}{llcccr}
\hline Cultivar & $\begin{array}{c}\text { Colour of } \\
\text { perianths }\end{array}$ & Quercetin & Kaempferol & Apigenin & Total \\
\cline { 3 - 6 } & & \multicolumn{4}{c}{ contents $\left(\mathrm{mg} \cdot \mathrm{g}^{-1}\right.$ of fresh weight \pm SD) } \\
\cline { 3 - 6 } & white & $4.27 \pm 0.23$ & $5.58 \pm 0.22$ & $2.53 \pm 0.06$ & $12.38 \pm 0.51$ \\
\hline Oscar & white & $5.16 \pm 0.24$ & $9.47 \pm 0.78$ & $3.17 \pm 0.23$ & $17.80 \pm 1.25$ \\
Pax & white & $3.15 \pm 0.29$ & $2.38 \pm 0.26$ & $2.63 \pm 0.31$ & $8.16 \pm 0.86$ \\
Biała Dama & white & $5.43 \pm 0.31$ & $5.91 \pm 0.35$ & $8.24 \pm 0.72$ & $19.58 \pm 1.39$ \\
White Virgin & white & $2.35 \pm 0.18$ & $1.09 \pm 0.08$ & $1.34 \pm 0.05$ & $4.78 \pm 0.31$ \\
Diana & yellow & $6.01 \pm 0.13$ & $3.60 \pm 0.16$ & $5.13 \pm 0.11$ & $14.74 \pm 0.39$ \\
Profesor Wóycicki & yellow & $4.99 \pm 0.27$ & $2.52 \pm 0.13$ & $6.68 \pm 0.12$ & $14.19 \pm 0.52$ \\
Calypso & & & &
\end{tabular}

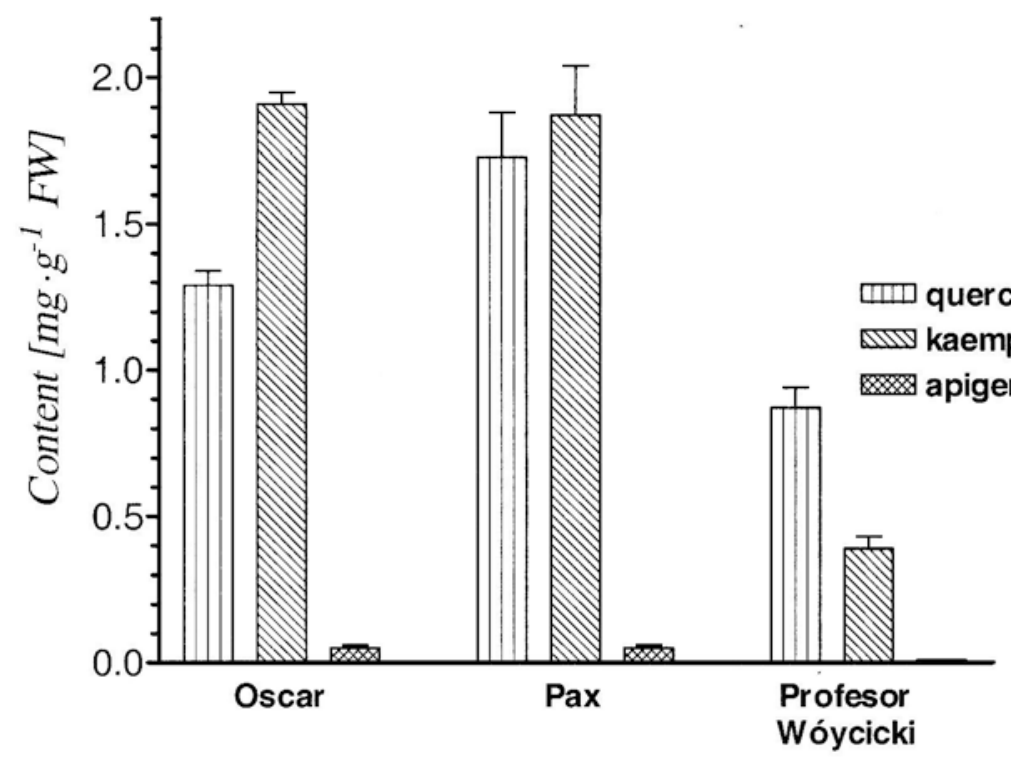

Fig. 1. Content of flavonoids in white perianth of cvs. Oscar and Pax, and in yellow perianth of cv. Profesor Wóycicki 
The flavonoids are present only as glycosides. In our preliminary studies we have not found in tulip tissues measurable quantities of quercetin, kaempferol and apigenin as a underivatized aglycones (data not shown). Unexpectedly, perianths of white tulip cultivars (Oscar and Pax) contained much more glycosides of quercetin and kaempferol than perianths of yellow cultivar - Profesor Wóycicki. It seems like flavonoid glycosides occur there have white colour, or $\mathrm{pH}$ of tissue caused such colour. Colour of perianths in cv. Profesor Wóycicki tulips is affected by presence of carotenoids, probably. S h i b a t a and I s h i k u r a (1960) showed that yellow cultivars of tulips contained kaempferol and quercetin glycosides, and violoxanthin as main component. Red, orange, pink and purple perianths of tulip contains glycosides of cyanidin, pelargonidin and delphinidin, carotenoids and flavonol glycosides: quercetin, kaempferol and myricetin (S h i b a t a and I s h i k u r a, 1960).

Anthers of all studied tulip cultivars had yellow colour. Concentration of all investigated flavonoids was much higher than in perianths (Table 1). Anthers contained glycosides of apigenin, quercetin and kaempferol in similar contents. Lowest amounts of flavonoids were found in anthers of cv. Biała Dama and cv. Diana (with white perianths). Total concentration of flavonoids ranged from $4.78 \mathrm{mg} \cdot \mathrm{g}^{-1}$ (cv. Diana) up to $19.57 \mathrm{mg} \cdot \mathrm{g}^{-1} \mathrm{FW}$ (cv. White Virgin). The level of flavonoid glycosides in tulip anthers is exceptionally high, and is comparable to that found in dry scales of onion ( $\left.10-30 \mathrm{mg} \cdot \mathrm{g}^{-1} \mathrm{DW}\right)$. According to results published by $\mathrm{S} \mathrm{tr} \mathrm{a} \mathrm{c} \mathrm{k} \mathrm{et} \mathrm{al.} \mathrm{(1981)}$ pollen of tulip cv. Apeldoorn contained several glycosides of quercetin, kaempferol and isorhamnetin. Colour of anthers in tulip cv. Apeldoorn is violet. In our investigations we found in yellow anthers (on base of retention time) the presence of apigenin. In extract from tulip anthers fortified with known amounts of standard, height and area of apigenin peak increased proportionally. It is possible that yellow anthers contain apigenin, although in the violet anthers and pollen isorhamnetin was found. For proving of the presence in tulip anthers of apigenin glycosides further studies are planned.

$\mathrm{Valadon}$ and M u m m r y (1968) have shown the occurrence of many carotenoids in yellow perianths, yellow anthers, yellow stigmas and deep orange filaments of tulip cv. Golden Harvest. However our studies carried out on yellow and white tulip perianths and yellow anthers, have indicated that its colour may be affected by presence of different flavonoids too.

\section{REFERENCES}

B u d z i a n o w s k i J., 1991. Six flavonol glucuronides from Tulipa gesneriana. Phytochemistry, 30: 1679-1682.

F o r m i c a J. V., R e g e l s o n W., 1995. Rewiev of biology of quercetin and related bioflavonoids. Food Chem. Toxicol., 33: 1061-1080.

$\mathrm{H}$ a le v y A. H., A s e n S., 1959. Identification of the anthocyanins in petals of tulip varieties Smiling Queen and Pride of Haarlem. Plant Physiol., 34: 494-499.

H a r b or n e J. B., 1994. The flavonoids. Chapman and Hall. London.

H e d i n P. A., W a n g e a S. K., 1986. Roles of flavonoids in plant resistance to insects. In: Progress in Clinical and Biological Research. Vol. 213. Ed.: V. Cody, E. Middleton, Jr., and J.B. Harborne. Alan R. Liss, New York: 87-100. 
He r r m a n n K., 1988. On the occurrence of flavonol and flavone glycosides in vegetables. Zeits. Lebensmittel Unters.-Forschung., 186: 1-5.

H e r t o g M. G. L., H o $11 \mathrm{~m}$ a n P. C. H., K a t a n M. B., 1992. Content of potentially anticarcinogenic flavonoids of 28 vegetables and fruits commonly consumed in the Netherlands. J. Agric. Food Chem., 40: 2379-2383.

H o r b o w i c z M., 1999. Changes of the flavonols content in onion during the vegetation period and storage. Veget. Crops Res. Bull., 50: 81-91.

H o r b o w i c z M., 2000. Występowanie, biosynteza i właściwości biologiczne flawonoli. Postępy Nauk Roln., 2: 3-18.

H o r b ow i c z M., K o t l i ń s k a T., 1998. Diversity of flavonol contents in some of wild and cultivated Allium species. Zesz. Probl. Post. Nauk Roln., 463: 529-537.

I w a s h i n a T., 2000. The structure and distribution of the flavonoids in plants. J. Plant Res., 113: 287-299.

L a r s o n R. A., 1988. The antioxidants of higher plants. Phytochemistry, 27: 969-971.

Merken H. M., B e e c h e r G. R., 2000. Measurement of food flavonoids by high-performance liquid chromatography: a review. J. Agric. Food Chem., 48: 577-599.

M o o r e T. C., 1989. Auxins. In: Biochemistry and Physiology of Plant Hormones. SpringerVerlag, New York.

$\mathrm{N}$ a k a y a m a M., Ya m a g u c h i M., U r a sh i ma O., K a n Y., Fukui Y., Y a magu c h i Y., K o s h i o k a M., 1999. Anthocyanins in the dark purple anthers of Tulipa gesneriana: identification of two novel delphinidin 3-O-(6-O-(acetyl- $\alpha$-rhamnopyranosyl)-B-glucopyranosides. Biosci. Biotechnol. Biochem., 63: 1509-1511.

$\mathrm{N}$ i e u w hof M., V a n R a a m s o n k L. W. D., V a n Ei j k J. P., 1990. Pigment composition of flowers of Tulipa species as a parameter for biosystematic research. Biochem. Syst. Ecol., 18: 399-404.

Pat i I S. B., Pi ke L. M., Y o o K. S., 1995. Variation in the quercetin content in different colored onions (Allium cepa L.). J. Amer. Soc. Hort. Sci., 120: 909-913.

P i e t t a P.-G., 2000. Flavonoids as antioxidants. J. Natur. Prod., 63: 1035-1042.

V a n R a a m s d o n k L.W.D., 1993. Flower pigment composition in Tulipa. Genet. Resour. Crop Evol., 40: 49-54.

$\mathrm{S}$ h i b a t a M., I s h i k u r a N., 1959. Anthocyanins in tulip flowers (Tulipa gesneriana, Tulipa fosteriana and Tulipa eichleri). Naturwiss., 46: 601-602.

S h i b a t a M., I s h i k u r a N., 1960. Paper chromatographic survey of anthocyanin in tulip flowers. Jap. J. Bot., 17: 230-238.

$\mathrm{S} \mathrm{h}$ i b a t a M., S a k a i E., 1961. Concerning the anthocyanins of two garden varieties of Tulipa gesneriana. The Botanical Magazine, Tokyo, 74: 186-189.

$\mathrm{S} \mathrm{h}$ i b a t a M., Y o s h i t a m a K., 1968. On anthocyanin crystals isolated from stamina of tulip-flowers (cultivar „Red Emperor”). Kumamoto J. Sci., Ser. B, Sec. 2, 9: 28-34.

S t r a c k D., S a c h s G., W i e r m a n n R., 1981. Pollen of Tulipa cv. „Apeldoorn” as an accumulation site of flavonol di- and triglycosides. Z. Pflanzenphysiol., 103: 291-296.

T o m a s- B a r beran F. A., M a i 11 a r d M., H o s t e $11 \mathrm{~m}$ a n K., 1988. Antifungal flavonoids from the leaf structures of Helichrysum nitens and from stem bark of Erythrina berteroana. In: Progress in Clinical and Biological Research. Vol. 280. Ed.: V. Cody, E. Middleton, Jr., J.B. Harborne and A. Beretz. Alan R. Liss, New York: 61-65.

Tors k a n g r poll K., Fos sen T., An derse n O. M., 1999. Anthocyanin pigments of tulips. Phytochemistry, 52: 1687-1692. 
To yod a M., T an a k K., Hosh in o K., A ki y a ma H., T a n i mura A., S a it to Y., 1997. Profiles of potentially antiallergic flavonoids in 27 kinds of health tea and green tea infusions. J. Agric. Food Chem., 45: 2561-2564.

V a 1 a d o n L. R. G., M u m m e r y R. S., 1968. Carotenoids in floral parts of a narcissus, a daffodil and a tulip. Biochem. J., 106: 479-484.

\title{
Flawonoidy w białym i żółtym okwiecie i żółtych pylnikach tulipanów (Tulipa gesneriana L.)
}

\author{
Streszczenie
}

Analizowano zawartość flawonoidów (metodą HPLC) w białym i żóttym okwiecie i w żółtych pylnikach kilku odmian tulipanów w okresie pełni kwitnienia. W żółtych pylnikach analizowanych odmian (Oscar, Pax, Profesor Wóycicki, Biała Dama, White Virgin, Calypso, Diana) wykazano wysoką zawartość kwercetyny $(2,35$ - 6,01 $\mathrm{mg} \cdot \mathrm{g}^{-1}$ s.m. $)$, kempferolu $\left(1,09-9,47 \mathrm{mg} \cdot \mathrm{g}^{-1}\right.$ ś.m. $)$ i apigeniny $\left(1,34-8,24 \mathrm{mg} \cdot \mathrm{g}^{-1}\right.$ ś.m.). W białym okwiecie odmian Oscar i White Virgin stwierdzono również wysoki poziom kwercetyny $\left(1,30-1,80 \mathrm{mg} \cdot \mathrm{g}^{-1}\right.$ ś.m. $)$ i kempferolu $\left(1,90 \mathrm{mg} \cdot \mathrm{g}^{-1}\right.$ ś.m. $)$, a tylko ilości śladowe apigeniny. W żółtym okwiecie odmiany Profesor Wóycicki zawartość kwercetyny i kempferolu była dużo mniejsza niż w białym okwiecie odmian Oscar i White Virgin, a brak było apigeniny. Tak więc żółte pylniki i biały i żółty okwiat odmian tulipanów są bogatym źródłem flawonoidów. 